\title{
ANTICORPOS CONTRA O HERPESVÍRUS BOVINO TIPO 1 (BoHV-1) NAS DEZ REGIÕES DE PLANEJAMENTO DO ESTADO DE GOIÁS, BRASIL
}

\author{
Ingrid Bortolin Affonso, ${ }^{1}$ José Gabriel Amoril,${ }^{2}$ Bruna Alexandrino, ${ }^{1}$ Maria da GlóRia Buzinaro, ${ }^{3}$ \\ Andrea Souza Ramos de Medeiros ${ }^{4}$ e Samir Issa Samara ${ }^{5}$ \\ 1. Pós-graduanda da FCAV/UNESP. E-mail: ibaffonso@gmail.com \\ 2. Médico veterinário, Ministério da Agricultura, Pecuária e Abastecimento, SIPA/DFA/GO \\ 3. Professora assistente doutora do Departamento de Medicina Veterinária Preventiva e Reprodução Animal, FCAV/UNESP \\ 4. Auxiliar do Laboratório de Viroses da Reprodução do Departamento de Medicina Veterinária Preventiva e Reprodução Animal,FCAV/UNESP \\ 5. Professor adjunto do Departamento de Medicina Veterinária Preventiva e Reprodução Animal, FCAV/UNESP.
}

\section{RESUMO}

Este estudo investigou a presença e o título de anticorpos contra o herpesvírus bovino tipo $1(\mathrm{BoHV}-1)$ em bovinos em idade de abate pertencentes às dez regiões de planejamento do Estado de Goiás. Para tanto, 660 amostras de soro foram colhidas em frigoríficos sob inspeção federal e submetidas à pesquisa de anticorpos neutralizantes pelo teste de vírus-neutralização. Os resultados mostraram que $84,5 \%$ das amostras de soro foram reagentes para o BoHV-1, ao passo que as análises regionalizadas detectaram índices que variaram de 63,4\% a $100 \%$. Evidenciaram-se $36,3 \%$ de animais com elevados títulos de anticorpos neutralizantes. Nesse sentido, a Região do Entorno do Distrito Federal apresentou a maior porcentagem de animais com títulos elevados $(65,8 \%)$ e a Região do Sudoeste Goiano, a menor (13,6\%). A ocorrência de grande número de bovinos reagentes com elevados títulos de anticorpos sugere o curso de infecções ativas ou reativadas nesses animais.

PALAVRAS-CHAVES: Anticorpos, BoHV-1, herpesvírus bovino tipo 1, vírus-neutralização.

\section{ANTIBODIES AGAINST BOVINE HERPESVIRUS TYPE 1 (BoHV-1) IN THE TEN PLANNING REGIONS OF GOIÁS STATE, BRAZIL}

This study investigated the presence of antibodies and antibodies titers against bovine herpesvirus type $1(\mathrm{BoHV}-1)$ in bovines at slaughter age in the ten planning regions of Goiás State. Blood samples (660) were collected in slaughterhouses under federal inspection and they were tested for neutralizing antibody by virus neutralization test. The results showed that $84.5 \%$ of serum samples were positive for BoHV-1, while the regionalized analysis found rates varying from $63.4 \%$ to $100 \%$. This study revealed $36.3 \%$ of animals with high titers of neutralizing antibodies. The region surrounding Brasilia presented the highest percentage of animals with high titers $(65.8 \%)$ and the Southeast Region of Goiás, the lowest $(13.6 \%)$. The occurrence of high percentage of reagents with high antibody levels suggests the course of BoHV-1 active or reactivated infections among these animals.

KEYWORDS: Antibodies, bovine herpesvirus type 1, BoHV-1, virus neutralization. 


\section{INTRODUÇÃO}

O herpesvírus bovino tipo 1 (BoHV-1), que pertence à família Herpesviridae, subfamília Alphaherpesvirinae, gênero Varicellovirus, é um importante agente infeccioso dos bovinos que ocasiona perdas expressivas na pecuária (HAGE et al., 1996). Este agente pode causar manifestações respiratórias, como a rinotraqueíte infecciosa bovina (IBR), e genitais (vulvovaginite e balanopostite pustular infecciosa, IPV/IPB). Entretanto, as consequências mais severas são as falhas reprodutivas, como abortos, infertilidade e natimortalidade (TAKIUCHI et al., 2005).

Após a infecção primária, o vírus permanece latente em gânglios nervosos do hospedeiro, tornando o animal portador por toda a sua vida. A reativação do vírus nos sítios nervosos ocorre após períodos de imunossupressão, como estresse, transporte e parição, ocasiões em que o portador pode excretar e transmitir o vírus para outros animais do rebanho (ACKERMANN et al., 1982).

Dos testes sorológicos para a identificação de anticorpos, a vírus-neutralização (VN) e o ensaio imunoenzimático (ELISA) são os mais frequentemente empregados, inclusive por recomendação da OIE (2007). Os estudos realizados no Brasil com essas técnicas têm demonstrado uma distribuição de anticorpos para o BoHV-1 variável nos rebanhos brasileiros (TAKIU$\mathrm{CHI}$ et al., 2001). Há relatos na literatura variando de 10,56\% de soropositividade (KRUGER et al., 1991) a 86\% (RICHTZENHAIN et al., 1999). Especificamente para o Estado de Goiás, ANUNCIAÇÃO et al. (1989) encontraram um percentual de soropositividade para o BoHV-1 de 85,7\%; FARIA et al. (2003) de 69,4\%; VIEIRA et al. (2003) de 83\% e BARBOSA et al. (2005) de $51,9 \%$ de bovinos reagentes, sendo este último a prevalência encontrada em todo o referido estado. Essas diferenças encontradas no percentual de bovinos soropositivos são entendidas não só como consequência da localização da amostragem, mas também do tipo de população estudada, idade dos animais, fatores de manejo, além das formas diferentes da amostragem populacional e de diagnóstico (LOVATO et al., 1995).

Em relação às medidas de controle e profilaxia da enfermidade, não existe um procedimento padrão (ALFIERI et al., 1998; DEL FAVA, 2002). O mais comum é a utilização de vacinas para prevenção da manifestação de sinais clínicos, induzindo a produção de anticorpos (SILVA et al., 2007).

Objetivou-se com este trabalho, investigar a presença e os níveis de anticorpos contra o BoHV-1 pelo teste de $\mathrm{VN}$ em bovinos em idade de abate, estatisticamente representativos das populações das distintas regiões de planejamento do Estado de Goiás.

\section{MATERIAL E MÉTODOS}

\section{Amostragem}

Durante o ano de 2007, foram colhidas aleatoriamente 660 amostras de sangue bovino independentemente do sexo, com idade entre dezoito e sessenta meses durante o abate regular em frigoríficos sob inspeção federal, localizados na região Metropolitana de Goiânia e no município de Rio Verde. Não havia a informação se os animais eram vacinados ou não contra o BoHV-1. As amostras de sangue foram colhidas durante a sangria dos animais, na quantidade de $5 \mathrm{~mL}$ por animal, em tubos de vidro, os quais posteriormente foram centrifugados a $1.800 \mathrm{G}$ durante cinco minutos. Com este processo, obtiveram-se os soros que foram separados e armazenados à temperatura de $-20^{\circ} \mathrm{C}$ até o momento de uso.

O número de amostras a serem colhidas foi calculado estatisticamente de acordo com ASTUDILLO (1979). Utilizou-se uma estimativa de animais positivos para BoHV-1 de $70 \%$ definida pela média dos extremos de prevalências já encontradas na literatura para o Estado de Goiás (ANUNCIAÇÃO et al., 1989; BARBOSA et al., 2005). Assim, $o$ número de amostras foi definido pela fórmula $n$ $=Z^{2} \mathrm{pq} /(\mathrm{p} . \mathrm{d} / 100)^{2}$. Nesta fórmula, $n$ representa o número de amostras, $Z$ é igual a $1-\alpha$ (um menos alfa) e refere-se ao grau de confiança, $p$ é a estimativa de animais positivos para BoHV-1 (70\%), $q$ é igual a $1-p$ e $d$ é o erro admitido (5\%). O valor de $Z$ foi obtido a partir de Tabelas sobre a curva de distribuição normal. Utilizou-se um nível de confiança de $\alpha=0,05(95 \%)$.

O número de amostras foi adequado de acordo com a população bovina de cada uma das regiões de planejamento, caracterizadas pela Superintendência de Estatística, Pesquisa e Informação do Estado de Goiás (GOIÁS, 2005), como apresentadas na Figura 1. A estratificação amostral está detalhada na Tabela 1. 


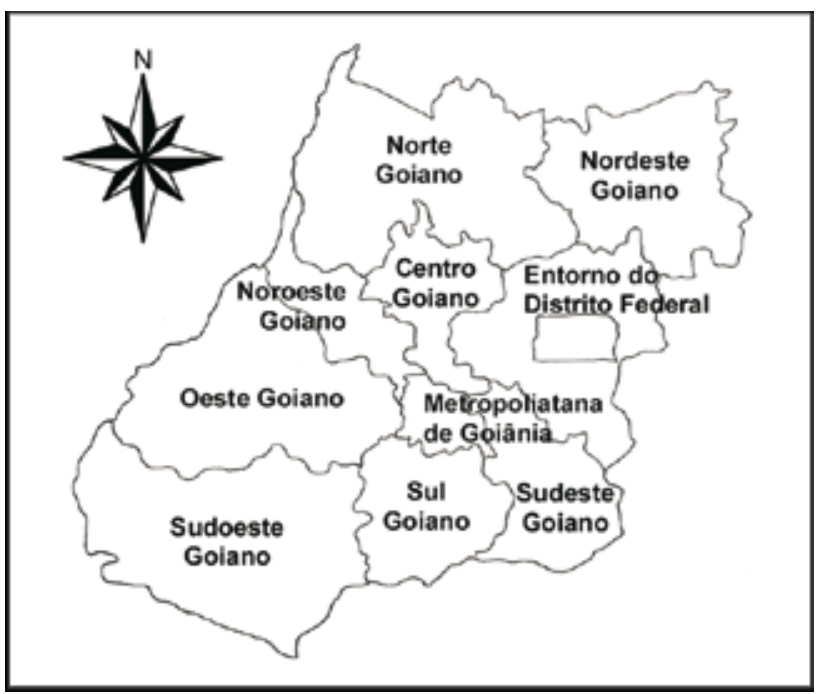

FIGURA 1. Mapa representativo das regiões de planejamento do Estado de Goiás (adaptado de: http://www.seplan.go.gov.br/sepin).

TABELA 1. Procedência das amostras de soro bovino que foram utilizadas no experimento depois da estratificação matemática realizada de acordo com a população bovina de cada região de planejamento do Estado de Goiás, segundo o cálculo proposto por ASTUDILLO (1979)

\begin{tabular}{|c|c|c|c|}
\hline Localização & $\begin{array}{l}\text { População } \\
\text { bovina } \\
\text { estimada* }\end{array}$ & $\begin{array}{c}\% \text { de } \\
\text { representação }\end{array}$ & $\begin{array}{l}\text { Número de } \\
\text { amostras }\end{array}$ \\
\hline \multicolumn{4}{|l|}{ Região 1} \\
\hline $\begin{array}{l}\text { Metropolitana de } \\
\text { Goiânia }\end{array}$ & 399.850 & $1,98 \%$ & 13 \\
\hline $\begin{array}{l}\text { Região } 2 \\
\text { Centro Goiano }\end{array}$ & 1.538 .570 & $7,65 \%$ & 51 \\
\hline $\begin{array}{l}\text { Região } 3 \\
\text { Norte Goiano }\end{array}$ & 3.516 .977 & $17,49 \%$ & 115 \\
\hline $\begin{array}{l}\text { Região } 4 \\
\text { Nordeste Goiano } \\
\text { Região } 5\end{array}$ & 911.888 & $4,53 \%$ & 30 \\
\hline $\begin{array}{l}\text { Entorno do Distrito } \\
\text { Federal }\end{array}$ & 1.243 .212 & $6,18 \%$ & 41 \\
\hline $\begin{array}{l}\text { Região } 6 \\
\text { Sudeste Goiano }\end{array}$ & 1.345 .090 & $6,69 \%$ & 44 \\
\hline $\begin{array}{l}\text { Região } 7 \\
\text { Sul Goiano }\end{array}$ & 1.958 .397 & $9,59 \%$ & 63 \\
\hline $\begin{array}{l}\text { Região } 8 \\
\text { Sudoeste Goiano }\end{array}$ & 3.618 .247 & $17,99 \%$ & 119 \\
\hline $\begin{array}{l}\text { Região } 9 \\
\text { Oeste Goiano }\end{array}$ & 4.240 .551 & $21,09 \%$ & 139 \\
\hline $\begin{array}{l}\text { Região } 10 \\
\text { Noroeste Goiano }\end{array}$ & 1.359 .111 & $6,76 \%$ & 45 \\
\hline Total & 20.101 .889 & $100 \%$ & 660 \\
\hline
\end{tabular}

* População bovina estimada para o ano de 2004 - dados da SEPIN/SEPLAN/GO (disponível em http://www.seplan.go.gov.br/sepin).
Exame laboratorial

As amostras foram inativadas em banho-maria a $56^{\circ} \mathrm{C}$ por trinta minutos, e a seguir examinadas em duplicata pelo teste de $\mathrm{VN}$ de modo preconizado pela OIE (2007), utilizando microplacas de 96 cavidades, a partir da diluição 1:2 até a diluição 1:1024. Como antígeno utilizou-se a amostra Nebraska BoHV-1, proveniente da Universidade Estadual de Londrina (UEL), ajustada a uma concentração de 200 TCID $_{50}$ por cavidade, titulado anteriormente pelo método de REED \& MUENCH (1938). Para evitar reações falsas, em cada placa foram feitos controles de célula e de citotoxicidade dos soros, além de uma placa de retrotitulação para o vírus utilizado. A mistura sorovírus foi incubada por 24 horas e, após este período, adicionaram-se células de linhagem contínua de rins de bovino - Madin \& Darby bovine kidney (MDBK, ATCC CCL-22), mantidas em frascos de poliestireno (TTP®), em meio essencial mínimo (MEM; GIBCO BRL), adicionado de $10 \%$ de soro fetal bovino (SFB; GIBCO BRL) e sem a adição de antibiótico. As microplacas foram acondicionadas em estufa com tensão de $\mathrm{CO}_{2}$ controlada a $5 \%$, em temperatura de $37^{\circ} \mathrm{C}$ por um período variável de 72 a 120 horas. Para a leitura, a amostra de soro considerada reagente pela presença de anticorpos foi aquela que neutralizou o vírus a partir da diluição 1:2. O título de anticorpos foi expresso como a recíproca da maior diluição em que não se observou efeito citopatogênico. Como as amostras foram testadas em duplicata, calculou-se o título de cada amostra utilizando-se a média geométrica.

Análise estatística

O teste exato de Fisher (GraphPad® Prism v. 5.0 software) foi utilizado para comparar as variáveis região e resultados do teste sorológico (títulos menores ou iguais a 256 e maiores que 256).

\section{RESULTADOS E DISCUSSÃO}

Considerando-se que o ponto de partida para a análise de problemas de doenças em populações depende de uma caracterização epidemiológica bem definida da enfermidade a pesquisar-se, foi proposto o presente estudo sobre o BoHV-1 que levou em consideração as áreas de planejamento e sua população bovina. Para 
isto, pesquisaram-se os níveis de anticorpos entre os animais em idade de abate por meio de amostragem estratificada em dez regiões de planejamento do Estado de Goiás. O resultado geral e específico por região está apresentado na Tabela 2 .

TABELA 2. Resultados obtidos nas amostras de soro bovino analisadas pelo teste de vírus-neutralização para o BoHV-1, nas diferentes regiões de planejamento do Estado de Goiás

\begin{tabular}{|c|c|c|}
\hline \multirow[b]{2}{*}{ Região } & \multicolumn{2}{|c|}{ Número de amostras } \\
\hline & $\begin{array}{c}\text { Positivos/Total } \\
(\%)\end{array}$ & $\begin{array}{c}\text { Título }>256 \\
(\%)\end{array}$ \\
\hline $\begin{array}{l}\text { Região } 1 \\
\text { Metropolitana de } \\
\text { Goiânia }\end{array}$ & $10 / 13(76,9)$ & $5(38,4)$ \\
\hline $\begin{array}{l}\text { Região } 2 \\
\text { Centro Goiano }\end{array}$ & $45 / 51(88,2)$ & $12(23,5)$ \\
\hline $\begin{array}{l}\text { Região } 3 \\
\text { Norte Goiano }\end{array}$ & $104 / 115(90,4)$ & $47(40,8)$ \\
\hline $\begin{array}{l}\text { Região } 4 \\
\text { Nordeste Goiano }\end{array}$ & $30 / 30(100)$ & $8(26,6)$ \\
\hline $\begin{array}{l}\text { Região } 5 \\
\text { Entorno do Distrito } \\
\text { Federal }\end{array}$ & $41 / 41(100)$ & $27(65,8)$ \\
\hline $\begin{array}{l}\text { Região } 6 \\
\text { Sudeste Goiano }\end{array}$ & $30 / 44(68,1)$ & $6(13,6)$ \\
\hline $\begin{array}{l}\text { Região } 7 \\
\text { Sul Goiano }\end{array}$ & $40 / 63(63,4)$ & $9(14,2)$ \\
\hline $\begin{array}{l}\text { Região } 8 \\
\text { Sudoeste Goiano }\end{array}$ & $101 / 119(84,8)$ & $38(31,9)$ \\
\hline $\begin{array}{l}\text { Região } 9 \\
\text { Oeste Goiano }\end{array}$ & $117 / 139(84,1)$ & $67(48,2)$ \\
\hline $\begin{array}{l}\text { Região } 10 \\
\text { Noroeste Goiano }\end{array}$ & $40 / 45(88,8)$ & $21(46,6)$ \\
\hline Total & $558 / 660(84,5)$ & $240(36,3)$ \\
\hline
\end{tabular}

Detectaram-se 84,5\% (558/660) de animais reagentes no teste de VN. Este resultado foi muito semelhante aos $83 \%$ encontrados por VIEIRA et al. (2003) em pesquisa realizada anteriormente no mesmo estado, assim como semelhante aos $81,7 \%$ registrados no Rio Grande do Sul (RAVAZZOLO et al., 1989) e
$86 \%$ verificados no Mato Grosso do Sul (RICHTZENHAIN et al., 1999). BARBOSA et al. (2005), em estudo da prevalência dessa enfermidade para o estado, observaram um índice de 51,9\%. Todavia, quando consideraram-se apenas animais adultos com mais de 24 meses, o coeficiente foi de 73,1\%, índice um pouco menor do obtido no presente estudo. No entanto, esse resultado é maior que as prevalências determinadas em outras regiões do Brasil, a saber: 42,2 \% em São Paulo (MUELLER et al., 1981); 18,8\% no Rio Grande do Sul (LOVATO et al., 1995); 58,2\% em Minas Gerais (ROCHA et al., 2001); 62,6\% no Pará (MOLNÁR et al., 2001). Essas diferenças provavelmente são decorrentes da metodologia empregada, principalmente no que se refere à forma de amostragem, região selecionada para o estudo e teste sorológico empregado (RICHTZENHAIN et al., 1999).

A elevada soropositividade repetiu-se em todas as regiões em estudo, sendo que em duas, na Região 4 (Nordeste Goiano) e Região 5 (Entorno do Distrito Federal), foram identificados $100 \%$ de animais reagentes. Demonstrou-se que a Região 8 (Sudoeste Goiano) manteve índices de soropositividade semelhantes aos $85,7 \%$ encontrados em pesquisa realizada na mesma região há duas décadas (ANUNCIAÇÃO et al., 1989). Entretanto, o resultado encontrado para a Região 1 (Metropolitana de Goiânia) foi um pouco superior aos $69,4 \%$ encontrados por FARIA et al. (2003), nesta mesma região. Esses dados confirmam a endemicidade e a grande dispersão desse vírus em Goiás.

Conforme indicado na Tabela 2 e Figura 2, em relação à titulação de anticorpos, constatou-se que $36,3 \%$ das amostras analisadas tiveram títulos superiores a 256. Analisando a resposta de anticorpos induzida por diferentes vacinas para BoHV-1 disponíveis no mercado brasileiro, SILVA et al. (2007) observaram que em geral os títulos induzidos por estas vacinas foram baixos. Este fato pode sugerir que os animais que apresentaram títulos elevados podem ter passado por uma infecção recente ou que houve uma reativação do BoHV-1 que estava em latência nos animais.

Os resultados tabulados por região, quando submetidos ao teste exato de Fisher, mostraram diferenças significativas $(p<0,05)$ entre as variáveis reagentes/ não reagentes e título de anticorpos maiores que 256 , conforme apresentado na Tabela 3. 
TABELA 3. Resultados da análise pelo teste exato de Fisher para as regiões de planejamento do Estado de Goiás que obtiveram associações significativas entre a variável região, e o resultado do título de anticorpos no teste de vírus-neutralização (títulos maiores que 256)

\begin{tabular}{|c|c|c|c|}
\hline & & $\mathrm{P}$ & $\begin{array}{l}\text { Odds ratio } \\
(\mathrm{IC} * 95 \%)\end{array}$ \\
\hline $\begin{array}{l}\text { Região } 2 \\
\text { Centro Goiano }\end{array}$ & $\begin{array}{c}\text { Região } 3 \\
\text { Norte Goiano }\end{array}$ & 0,0356 & $\begin{array}{c}0,445 \\
(0,211-0,939)\end{array}$ \\
\hline $\begin{array}{l}\text { Região } 2 \\
\text { Centro Goiano }\end{array}$ & $\begin{array}{c}\text { Região } 5 \\
\text { Entorno do Distrito Federal }\end{array}$ & $<0,0001$ & $\begin{array}{c}1,59 \\
(0,064-0,398)\end{array}$ \\
\hline $\begin{array}{l}\text { Região } 2 \\
\text { Centro Goiano }\end{array}$ & $\begin{array}{l}\text { Região } 9 \\
\text { Oeste Goiano }\end{array}$ & 0,0026 & $\begin{array}{c}0,331 \\
(0,159-0,685)\end{array}$ \\
\hline $\begin{array}{l}\text { Região } 2 \\
\text { Centro Goiano }\end{array}$ & $\begin{array}{c}\text { Região } 10 \\
\text { Noroeste Goiano }\end{array}$ & 0,00196 & $\begin{array}{c}0,352 \\
(0,147-0,842)\end{array}$ \\
\hline $\begin{array}{l}\text { Região } 3 \\
\text { Norte Goiano }\end{array}$ & $\begin{array}{c}\text { Região } 6 \\
\text { Sudeste Goiano }\end{array}$ & 0,0012 & $\begin{array}{c}4,38 \\
(1,72-11,18)\end{array}$ \\
\hline $\begin{array}{l}\text { Região } 3 \\
\text { Norte Goiano }\end{array}$ & $\begin{array}{l}\text { Região } 7 \\
\text { Sul Goiano }\end{array}$ & 0,0002 & $\begin{array}{c}4,15 \\
(1,87-9,21)\end{array}$ \\
\hline $\begin{array}{l}\text { Região } 4 \\
\text { Nordeste Goiano }\end{array}$ & $\begin{array}{c}\text { Região } 5 \\
\text { Entorno do Distrito Federal }\end{array}$ & 0,0017 & $\begin{array}{c}0,189 \\
(0,067-0,531)\end{array}$ \\
\hline $\begin{array}{l}\text { Região } 4 \\
\text { Nordeste Goiano }\end{array}$ & $\begin{array}{l}\text { Região } 9 \\
\text { Oeste Goiano }\end{array}$ & 0,0420 & $\begin{array}{c}0,3908 \\
(0,163-0,937)\end{array}$ \\
\hline $\begin{array}{l}\text { Região } 5 \\
\text { Entorno do Distrito Federal }\end{array}$ & $\begin{array}{c}\text { Região } 6 \\
\text { Sudeste Goiano }\end{array}$ & $<0,0001$ & $\begin{array}{c}12,21 \\
(4,163-35,84)\end{array}$ \\
\hline $\begin{array}{l}\text { Região } 5 \\
\text { Entorno do Distrito Federal }\end{array}$ & $\begin{array}{l}\text { Região } 7 \\
\text { Sul Goiano }\end{array}$ & $<0,0001$ & $\begin{array}{c}11,57 \\
(4,45-30,12)\end{array}$ \\
\hline $\begin{array}{l}\text { Região } 5 \\
\text { Entorno do Distrito Federal }\end{array}$ & $\begin{array}{c}\text { Região } 8 \\
\text { Sudoeste Goiano }\end{array}$ & 0,0002 & $\begin{array}{c}4,11 \\
(1,94-8,72)\end{array}$ \\
\hline $\begin{array}{l}\text { Região } 6 \\
\text { Sudeste Goiano }\end{array}$ & $\begin{array}{c}\text { Região } 8 \\
\text { Sudoeste Goiano }\end{array}$ & 0,0277 & $\begin{array}{c}0,336 \\
(0,131-0,865)\end{array}$ \\
\hline $\begin{array}{l}\text { Região } 6 \\
\text { Sudeste Goiano }\end{array}$ & $\begin{array}{l}\text { Região } 9 \\
\text { Oeste Goiano }\end{array}$ & $<0,0001$ & $\begin{array}{c}0,169 \\
(0,067-0,43)\end{array}$ \\
\hline $\begin{array}{l}\text { Região } 6 \\
\text { Sudeste Goiano }\end{array}$ & $\begin{array}{c}\text { Região } 10 \\
\text { Noroeste Goiano }\end{array}$ & 0,0011 & $\begin{array}{c}0,1805 \\
(0,064-0,511)\end{array}$ \\
\hline $\begin{array}{l}\text { Região } 7 \\
\text { Sul Goiano }\end{array}$ & $\begin{array}{c}\text { Região } 8 \\
\text { Sudoeste Goiano }\end{array}$ & 0,0122 & $\begin{array}{c}0,3553 \\
(0,159-0,794)\end{array}$ \\
\hline $\begin{array}{l}\text { Região } 7 \\
\text { Sul Goiano }\end{array}$ & $\begin{array}{l}\text { Região } 9 \\
\text { Oeste Goiano }\end{array}$ & $<0,0001$ & $\begin{array}{c}0,1791 \\
(0,082-0,391)\end{array}$ \\
\hline $\begin{array}{l}\text { Região } 7 \\
\text { Sul Goiano }\end{array}$ & $\begin{array}{c}\text { Região } 10 \\
\text { Noroeste Goiano }\end{array}$ & 0,0004 & $\begin{array}{c}0,1905 \\
(0,076-0,477)\end{array}$ \\
\hline $\begin{array}{l}\text { Região } 8 \\
\text { Sudoeste Goiano }\end{array}$ & $\begin{array}{l}\text { Região } 9 \\
\text { Oeste Goiano }\end{array}$ & 0,0109 & $\begin{array}{c}0,5041 \\
(0,303-0,839)\end{array}$ \\
\hline
\end{tabular}

*IC - Intervalo de Confiança 


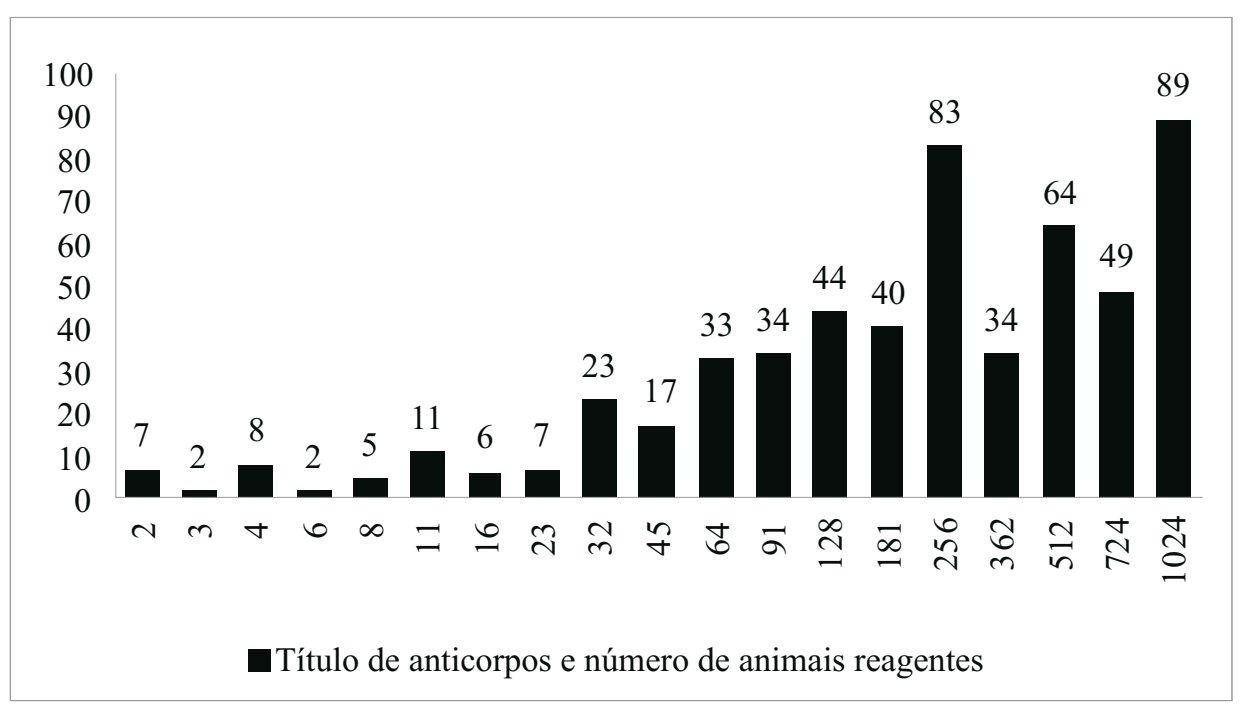

FIGURA 2. Título de anticorpos e número de animais reagentes por meio da titulação dos soros no teste de vírus-neutralização.

As diferenças encontradas no teste estatístico entre as regiões podem sugerir a existência de fatores responsáveis por maiores títulos de anticorpos em uma região do que em outra. Infecções reativadas ou atividade viral presentes nesses rebanhos podem explicar os elevados títulos encontrados. Dessa forma destaca-se a Região 5 (Entorno do Distrito Federal), pois apresentou diferença estatística em relação às demais, possuindo mais de $50 \%$ das amostras com títulos elevados (maiores que 256). Da mesma forma, as Regiões 6 (Sudeste Goiano) e 7 (Sul Goiano) também apresentaram diferença estatística, pois menos de $20 \%$ das amostras estavam com títulos elevados (Tabela 2). Nesse sentido, dada a elevada soropositividade e elevados títulos de anticorpos apresentados pelos animais em todas as regiões geográficas, tornase difícil estabelecer os prováveis fatores envolvidos nesta situação.

\section{CONCLUSÃO}

Os resultados do presente estudo confirmam elevada porcentagem de animais reagentes para o BoHV-1 no Estado de Goiás. Apesar de a análise estatística evidenciar diferenças entre as regiões de planejamento, a ocorrência de grande número de animais soropositivos com elevados títulos dificulta estabelecer os fatores responsáveis por essas diferenças, sugerindo a ocorrência de infecções ativas ou reativadas nesses rebanhos.

\section{AGRADECIMENTOS}

Aos funcionários do Ministério da Agricultura, Pecuária e Abastecimento (MAPA) de Goiânia, aos alunos Mônica Costa Oliveira e Felipe Jorge da Silva, da pós-graduação em Medicina Veterinária Preventiva da FCAV/UNESP, pela colaboração no desenvolvimento deste trabalho, e ao professor doutor Francisco de Carvalho Dias Filho da Universidade Federal de Goiás, pelo apoio no processamento das amostras. Os autores também agradecem aos revisores anônimos pelas sugestões feitas. Apoio financeiro: Fundação de Amparo à Pesquisa do Estado de São Paulo - FAPESP (Proc. $n^{\circ}$ 06/55901-9).

\section{REFERÊNCIAS}

ACKERMANN, M.; PETERHANS, E.; WYLER, R. DNA of the bovine herpesvirus type 1 in the trigeminal ganglia of latent infected calves. American Journal of Veterinary Research, v. 43, n. 1, p. 36-40, 1982.

ALFIERI, A. A.; ALFIERI, A. F.; KERLEI, C. M. Conseqüências da infecção pelo herpesvírus bovino tipo 1 sobre o sistema reprodutivo de bovinos. Semina: Ciências Agrárias, v. 19, n. 1, p. 86-93, 1998.

ANUNCIAÇÃO, A. V. M.; LEITE, R. C.; MOREIRA, E. C.; REIS, R. Presença de anticorpos para o herpesvírus bovino 1 (BHV-1) em bovinos nos estados de Minas gerais, Goiás e Rio de Janeiro através da prova de hemoaglutinação passiva. Arquivo Brasileiro de Medicina Veterinária e Zootecnia, v. 41, n. 5, p. 433-441, 1989. 
ASTUDILLO, V. M. Encuestas por muestreo para estudios epidemiológicos en poblaciones animales. Centro Paranamericano de Fiebre Aftosa. Serie de Manuales Didacticos, v. 12, 60p. 1979. Disponível em: < http://bvs1.panaftosa.org.br/local/File/textoc/ SerManDid12.pdf >. Acesso em: 11 mar. 2008.

BARBOSA, A. C. V. C.; BRITO, W. M. E. D.; ALFAIA, B. T. Soroprevalência e fatores de risco para a infecção pelo herpesvírus bovino tipo 1 (BHV-1) no Estado de Goiás, Brasil. Ciência Rural, v. 35, n. 6, p. 1368-1373, 2005.

DEL FAVA, C.; PITUCO, E. M.; D'ANGELO, J. L. Herpesvírus bovino tipo 1 (HVB-1): revisão e situação atual no Brasil. Revista de Educação Continuada, CRMV-SP, São Paulo, v. 5, n. 3, p. 300-312, 2002.

FARIA, B. O.; FRENEAU, G. E.; BRITO, W. M. E. D.; CAMPOS JÚNIOR, A. C. P.; VIEIRA, S. Estudo de anticorpos contra o herpesvírus bovino tipo 1 em municípios de entorno de Goiânia, GO. Revista Brasileira de Reprodução Animal, v. 27, n. 3, p. 543-545, 2003.

GOIÁS. Superintendência de Estatística, Pesquisa e Informação. SEPIN Regiões de Planejamento. Goiânia, 2005. Disponível em: < http://www.seplan.go.gov.br/sepin/, > Acesso em: 11 mar. 2008.

HAGE, J. J.; SCHUKKEN, Y. H.; BARKEMA, H. W. Population dynamics of bovine herpes 1 infection in a dairy herd. Veterinary Microbiology, v. 53, p. 317-343, 1996.

KRUGER, E. R.; KANTER, C. E.; PINTO, M. A. Presença de anticorpos neutralizantes contra o vírus da rinotraqueíte infecciosa bovina (IBR) em gado leiteiro na região de Curitiba, PR. Hora Veterinária, v. 75, p. 30-32, 1991.

LOVATO, L. T.; WEIBLEN, R.; TOBIAS, F. L.; MORAES, M. P. Herpesvirus bovino tipo 1 (HVB-1): inquérito soro-epidemiológico no rebanho leiteiro do estado do Rio Grande do Sul, Brasil. Ciência Rural, v. 25, n. 3, p. 425-430, 1995.

MOLNÁR, E.; CAMELO, A. S. A.; SILVA, E. B.; MOLNÁR, L. Prevalência da infecção pelo vírus da rinotraqueíte infecciosa bovina (IBR) em bubalinos e bovinos no Estado do Pará, Brasil. Revista Brasileira de Reprodução Animal, v. 25, n. 2, p. 252254, 2001.

MUELLER, S. B. K.; IKUNO, A. A.; MACHADO, T. S. Prevalência de anticorpos contra o vírus da rinotraqueíte infecciosa/ vulvovaginite pustular infecciosa (IBR/IPV) em bovinos do Estado de São Paulo. Arquivos do Instituto Biológico, v. 47, n. 2, p. 55-59, 1981.
OIE. Office International des Epizooties. International animal health code. Paris: OIE, 2007. Disponível em: $<$ http// www.oie. int>. Acesso em: 15 fev. 2007.

RAVAZZOLO, A. P.; DAL PIZZOL, M.; MOOJEN, V. Evidência da presença de anticorpos para o vírus da rinotraqueíte infecciosa dos bovinos em alguns municípios do Estado do Rio Grande do Sul. Arquivos da Faculdade de Veterinária da UFRGS, v. 17, p. 89-95, 1989.

REED, L. J.; MUENCH, H. A simple method of estimating 50 per cent end point. American Journal of Hygiene, v. 27, p. 493497, 1938.

RICHTZENHAIN L. J.; BARBARINI, O.; UMEHARA, O.; DE GRACIA, A. S.; CORTEZ, A.; HEINEMANN, M. B.; FERREIRA, F. Rinotraqueíte infecciosa bovina: levantamento sorológico nos Estados de Minas Gerais, Mato Grosso do Sul, São Paulo, Rio de Janeiro, Paraná e Rio Grande do Sul. Arquivos do Instituto Biológico, v. 66, n. 1, p. 83-88, 1999.

ROCHA, M. A.; GOUVEIA, A. M. G.; LOBATO, Z. I. P.; LEITE, R. C. Pesquisa de anticorpos para IBR em amostragem de demanda no Estado de Minas Gerais, 1990-1999. Arquivo Brasileiro de Medicina Veterinária e Zootecnia, v. 53, n. 6, p. 645-647, 2001.

SILVA, L. F.; WEIBLEN, R.; FLORES, E. F. Imunogenicidade de vacinas comerciais inativadas contra o herpesvírus bovino tipo 1 . Ciência Rural, v. 37, n. 5, p. 1471-1474, 2007.

TAKIUCHI E.; MÉDICI K. C.; ALFIERI A. F.; ALFIERI A. A. Bovine herpesvirus type 1 abortions detected by a semi-nested PCR in Brazilian cattle herds. Research in Veterinary Science, v. 79, n.1, p. 85-88, 2005.

TAKIUCHI, E.; ALFIERI, A. F.; ALFIERI, A. A. Herpesvírus bovino tipo 1: tópicos sobre a infecção e métodos de diagnóstico. Semina: Ciências Agrárias, v. 22, n. 2, p. 203-209, 2001.

VAN WUIJCKHUISE, L.; BOSCH, J.; FRANKEN, P.; FRANKENA, K.; ELBERS, A. R. W. Epidemiological characteristics of bovine herpesvirus 1 infections determined by bulk milk testing of all Dutch dairy herds. Veterinary Record, v. 142, p. 181-184, 1998.

VIEIRA, S.; BRITO, W. M. E. D.; SOUZA, W. J.; ALFAIA, B. T.; LINHARES, C. L. Anticorpos para o herpesvírus bovino 1 (BHV-1) em bovinos do Estado de Goiás. Ciência Animal Brasileira, v. 4, n. 2, p. 131-137, 2003. 